\title{
Efektivitas Discovery Learning untuk Meningkatkan Kemampuan Inferensi dan Penguasaan Konsep Kesetimbangan Kimia
}

\author{
Zelda Amini*, Tasviri Efkar, Emmawaty Sofya \\ Program Studi Pendidikan Kimia, Universitas Lampung, Indonesia \\ *Corresponding author: zeldaamini246@gmail.com
}

\begin{abstract}
Abstrcat: The effectiveness of discovery learning to improve inferencetion skill and mastery concept of chemical equilibrium. The goal of this research was describe the effectiveness of discovery learning model to improve inferencetion skill and mastery concept of chemical equilibrium. This research used quasi experimental method with a pretest-postest control grup design. Sampling was performed by using purposive technique with all of the 11th grade student in SMA Negeri 15 Bandar Lampung as population. This research used two classes as control and experimental class which they were obtained from XI MIA 3 and XI MIA 2 of academic year 2018-2019. The effectiveness of discovery learning was showed by the significant difference of $n$-Gain between control and experiment classes. The size associated with using effect size. The result obtained size of influence is great. The result of hypothesis testing showed that discovery learning model was effective to improve inferencetion skill and mastery concepts of chemical equilibrium.
\end{abstract}

Keywords: chemical equilibrium, discovery learning model, inferencetion skill, and mastery concepts.

\begin{abstract}
Abstrak: Efektivitas Discovery Learning untuk Meningkatkan Kemampuan Inferensi dan Penguasaan Konsep Kesetimbangan Kimia. Penelitian ini bertujuan untuk mendeskripsikan efektivitas model discovery learning untuk meningkatkan kemampuan inferensi dan penguasaan konsep materi kesetimbangan kimia. Metode penelitian ini adalah kuasi eksperimen dengan pretest-postest control grup design. Pengambilan sampel dilakukan dengan teknik purposive sampling yang dalam penelitian ini populasinya ialah seluruh siswa kelas XI MIA SMA Negeri 15 Bandar Lampung. Sampel pada penelitian ini adalah kelas XI MIA 3 dan XI MIA 2 Tahun Ajaran 2018-2019. Efektivitas model discovery learning ditunjukkan oleh adanya perbedaan rata-rata nilai $n$-Gain yang signifikan antara kelas kontrol dan kelas eksperimen. Ukuran pengaruh dihitung dengan menggunakan uji effect size. Hasilnya diperoleh ukuran pengaruh yang besar. Hasil pengujian hipotesis menunjukkan bahwa model discovery learning pada materi kesetimbangan kimia efektif dalam meningkatkan kemampuan inferensi dan penguasaan konsep.
\end{abstract}

Kata kunci: kesetimbangan kimia, pembelajaran berbasis penemuan, kemampuan inferensi, dan penguasaan konsep. 


\section{PENDAHULUAN}

Ilmu Pengetahuan Alam (IPA) adalah suatu kumpulan teori yang sistematis, penerapannya secara umum terbatas pada gejala-gejala alam, lahir dan berkembang melalui metode ilmiah seperti observasi dan eksperimen, serta menuntut sikap ilmiah seperti rasa ingin tahu, terbuka, jujur dan sebagainya (Trianto, 2010).

Konten ilmu kimia yang berupa konsep, hukum, dan teori, pada dasarnya merupakan produk dari rangkaian proses menggunakan sikap ilmiah. Oleh sebab itu, pembelajaran kimia harus memperhatikan karakteristik kimia sebagai proses, produk, dan sikap (Fadiawati, 2011). Ilmu kimia memiliki tiga komponen yang saling berkaitan satu sama lain yaitu ilmu kimia sebagai: (1) produk; (2) proses atau kerja ilmiah; dan (3) sikap ilmiah. Ilmu kimia sebagai produk yaitu berupa fakta, konsep, prinsip, hukum, dan teori, sedangkan sebagai proses atau kerja ilmiah yaitu metode ilmiah yang dilakukan para ilmuwan untuk memperoleh ilmu pengetahuan. Ilmu kimia sebagai sikap ilmiah yaitu sikap yang harus dimiliki seseorang dalam rangka memperoleh pengetahuan, sebagai contoh sikapjujur, teliti, hati-hati, dan sikap mulia lainnya.

Berdasarkan karakteristik ilmu kimia, maka seharusnya pembelajaran kimia di sekolah berlandaskan pada komponen ilmu kimia sebagai produk, proses, dan sikap ilmiah. Idealnya pembelajaran kimia di sekolah berpusat pada siswa (student center learning), sehingga dapat dikembangkan keterampilan proses sains (KPS) seperti mengamati, mengelompokkan, menafsirkan, meramalkan (prediksi), inferensi, serta mengkomunikasikan (Djamarah dan Zain, 2010).

Keterampilan proses sains diperoleh dari latihan kemampuan mental, fisik, dan sosial yang mendasar sebagai penggerak kemampuan yang lebih tinggi (Dimyati dan Mudjiono, 2002). Keterampilan proses sains (KPS) merupakan pendekatan pembelajaran yang berorientasi pada proses IPA (Rustaman, 2005).

Salah satu indikator keterampilan proses sains yaitu kemampuan inferensi (penarikan kesimpulan). Penarikan kesimpulan dilakukan berdasarkan apa yang telah diamati untuk menjelaskan sesuatu yang telah terjadi. Penginferensian berlangsung setelah melakukan suatu pengamatan untuk menafsirkan apa yang telah diamati (Kosasih, 2014).

Hasil observasi dan wawancara dengan guru mata pelajaran kimia yang telah dilakukan di SMA Negeri 15 Bandar Lampung, menunjukkan bahwa pembelajaran kimia yang sudah mengacu pada kurikulum 2013 ternyata masih berpusat pada guru (teacher centered learning) dengan metode ceramah, penugasan dan latihan.

Berdasarkan permasalahan yang ada, maka diperlukan upaya untuk melatih kemampuan siswa dalam melakukan penarikan kesimpulan (kemampuan inferensi) dan penguasaan konsep materi kesetimbangan kimia. Salah satu upaya tersebut adalah dengan menerapkan model pembelajaran yang melibatkan siswa aktif dalam pembelajaran yaitu model discovery learning. Pembelajaran dengan menggunakan model discovery learning diterapkan dengan siswa membangun pengetahuan mereka sendiri melalui suatu percobaan dan menemukan suatu prinsip dari percobaan tersebut (Joolingen, 1998).

Pembelajaran dengan menggunakan model discovery learning dapat mengembangkan cara belajar siswa aktif dengan menemukan sendiri, menyelidiki sendiri, maka hasil yang diperoleh akan setia dan tahan lama dalam ingatan, tidak akan mudah dilupakan siswa. Tahapan pada model discovery learning yaitu stimulation (pemberian rangsangan), problem statement (identifikasi masalah), data collection 
(pengumpulan data), data processing (pengolahan data), verification (pembuktian), dan generalization (pengambilan kesimpulan) (Hosnan, 2014).

Beberapa kelebihan dari model discovery learning, yaitu sebagai berikut :

a. Timbul rasa senang pada siswa, karena tumbuhnya rasa menyelidiki dan berhasil.

b. Siswa akan mengerti konsep dasar dan ide-ide lebih baik.

c. Dorongan untuk siswa berpikir dan bekerja atas inisiatif sendiri.

d. Siswa belajar dengan memanfaatkan berbagai jenis sumber belajar.

Adapun kekurangan model discovery learning yaitu (Hosnan, 2014):

1. Banyak waktu yang dibutuhkan, karena guru dituntut mengubah kebiasaan mengajar yang umumnya sebagai pemberi informasi menjadi fasilitator, motivator, dan pembimbing.

2. Kemampuan berpikir rasional siswa ada yang masih terbatas.

3. Tidak semua siswa dapat mengikuti pelajaran dengan cara ini.

Setiap model pembelajaran pasti memiliki kekurangan, namun kekurangan tersebut dapat diminimalisir agar berjalan secara optimal. Pembelajaran dengan model discovery akan efektif jika terjadi hal-hal berikut: (1) proses belajar dibuat secara terstruktur dengan hati-hati; (2) siswa memiliki pengetahuan dan keterampilan awal untuk belajar; (3) guru memberikan dukungan yang dibutuhkan siswa untuk melakukan penyelidikan (Kurniasih dan Sani, 2014).

Penelitian yang telah mengkaji tentang penerapan model discovery learning dilakukan oleh Utami (2015) terhadap siswa kelas XI IPA SMAN 7 Bandar Lampung yaitu model pembelajaran discovery learning efektif dalam meningkatkan keterampilan membedakan pada materi elektrolit dan non elektrolit. Sukawati (2016) menyatakan bahwa model discovery learning pada materi larutan penyangga efektif dalam meningkatkan keterampilan mengelompokkan dan keterampilan mengomunikasikan siswa. Hasil penelitian Rosaria (2018) menyatakan bahwa pembelajaran dengan model discovery learning efektif dalam meningkatkan keterampilan berpikir elaborasi dan penguasaan konsep pada materi asam basa Arrhenius.

Berdasarkan uraian di atas, maka dilakukan penelitian dengan judul efektivitas discovery learning untuk meningkatkan kemampuan inferensi dan penguasaan konsep kesetimbangan kimia.

Rumusan masalah dalam penelitian ini yaitu bagaimana efektivitas model discovery learning

pada materi kesetimbangan kimia untuk meningkatkan kemampuan inferensi dan penguasaan konsep? Tujuan penelitian ini untuk mendeskripsikan efektivitas model discovery learning dalam meningkatkan kemampuan inferensi dan penguasaan konsep materi kesetimbangan kimia.

\section{METODE PENELITIAN}

\section{Metode dan Desain Penelitian}

Metode penelitian yang digunakan dalam penelitian ini adalah kuasi eksperimen dengan pretest-postest control grup design (Fraenkel, 2012).

\section{Populasi dan Sampel}

Populasi dalam penelitian ini adalah semua siswa kelas XI MIA SMA Negeri 15 Bandar Lampung tahun ajaran 2018/2019 yang berjumlah 107 siswa dan tersebar dalam tiga kelas. Sampel dalam penelitian ini adalah dua kelas dari tiga kelas XI MIA SMA 
Negeri 15 Bandar Lampung. Teknik pengambilan sampel yang digunakan adalah teknik purposive sampling, diperoleh kelas XI MIA 2 sebagai kelas eksperimen dan kelas XI MIA 3 sebagai kelas kontrol.

\section{Perangkat Pembelajaran}

Variabel bebas pada penelitian ini adalah pembelajaran dengan model discovery learning dan pembelajaran konvensional. Variabel terikat dalam penelitian ini adalah kemampuan inferensi dan penguasaan konsep. Pada penelitian ini adapun perangkat pembelajaran yang digunakan yaitu silabus, Rencana Pelaksanaan Pembelajaran (RPP), Lembar Kerja Siswa (LKS), kisi-kisi soal pretes-postes, soal pretes-postes, rubrik penilaian soal pretes-postes, lembar observasi keterampilan guru dalam mengajar, lembar observasi keterampilan siswa,dan lembar observasi aktivitas siswa.

\section{Teknik Analisis Data}

Analisis data dilakukan meliputi validitas dan reliabilitas instrumen, keefektifan, dan ukuran pengaruh. Analisis data dihitung dengan bantuan software SPSS versi 22.0 for Windows dan Microsoft Office Excel.

Instrumen tes terdiri dari tiga butir soal uraian yang dikatakan valid apabila nilai $\mathrm{r}_{\text {hitung }}>\mathrm{r}_{\text {tabel }}$ dengan taraf signifikansi 0,05. Reliabilitas soal uraian ditentukan dengan rumus Alpha Cronbach. Soal dikatakan reliabel jika Alpha Cronbach $\geq \mathrm{r}_{\text {tabel. }}$ Kriteria derajat reliabilitas $\left(\mathrm{r}_{11}\right)$ ditunjukkan pada Tabel 1 (Fidiana, 2017):

Tabel 1. Kriteria derajat reliabilitas

\begin{tabular}{ll}
\hline Derajat reliabilitas $(\mathrm{r} 11)$ & Kriteria \\
\hline $0,80<\mathrm{r} 11 \leq 1,00$ & Sangat Tinggi \\
\hline $0,60<\mathrm{r} 11 \leq 0,80$ & Tinggi \\
\hline $0,40<\mathrm{r} 11 \leq 0,60$ & Sedang \\
\hline $0,20<\mathrm{r} 11 \leq 0,40$ & Rendah \\
\hline $0,00<\mathrm{r} 11 \leq 0,20$ & Sangat Rendah \\
\hline
\end{tabular}

Efektivitas model discovery learning ditentukan dari ketercapaian pada peningkatan kemampuan inferensi dan penguasaan konsep siswa yang diukur dengan nilai $n$-Gain yaitu selisish nilai pretes dan postes dari kedua kelas. Rumus $n$-Gain:

$$
\frac{(\text { nilai postes - nilai pretes) }}{(\text { nilai maksimum - nilai pretes) }}
$$

(Hake, 2002)

dengan kriteria $n$-Gain ditunjukkan pada Tabel 2.

Tabel 2. Kriteria skor $n$-Gain

\begin{tabular}{ll}
\hline Skor $n$-Gain & Kriteria \\
\hline$n$-Gain $>0,7$ & Tinggi \\
\hline $0,3<n$-Gain $\leq 0,7$ & Sedang \\
\hline$n$-Gain $\leq 0,3$ & Rendah \\
\hline
\end{tabular}


Efektivitas model discovery learning juga ditentukan dari kemampuan guru dalam mengelola pembelajaran discovery learning. Langkah-langkah yang dilakukan untuk analisis data kemampuan guru dalam mengelola pembelajaran (Suprayanti, 2016):

1. Hitung jumlah skor yang diberikan oleh pengamat untuk setiap aspek pengamatan, kemudian jumlah skor dihitung persentasenya.

2. Hitung rata-rata persentase kemampuan guru untuk setiap aspek pengamatan.

3. Data yang diperoleh ditafsirkan dengan tafsiran harga persentase kemampuan guru berdasarkan Tabel 3 (Sunyono, 2013):

Tabel 3. Kriteria kemampuan guru

\begin{tabular}{ll}
\hline Persentase & Kriteria \\
\hline $80,1 \%-100,0 \%$ & Sangat Tinggi \\
\hline $60,1 \%-80,0 \%$ & Tinggi \\
\hline $40,1 \%-60,0 \%$ & Sedang \\
\hline $20,1 \%-40,0 \%$ & Rendah \\
\hline $0 \%-20,0 \%$ & Sangat Rendah \\
\hline
\end{tabular}

Ukuran pengaruh (effect size) model discovery learning terhadap peningkatan kemampuan inferensi dan penguasaan konsep kesetimbangan kimia ditentukan berdasarkan nilai uji-t. Sebelum uji-t dilakukan, terlebih dahulu dilakukan uji normalitas dan uji homogenitas terhadap nilai $n$-Gain.

Kriteria normalitas dan homogenitas yaitu sampel dikatakan berdistribusi normal dan memiliki varians yang homogen, jika nilai sig. Kolmogorov-Smirnov Tes $>0,05$. Apabila sampel berdistribusi normal dan homogen, maka selanjutnya uji statistik parametrik yaitu uji independent sample t-test pada $n$-Gain kedua kelas dengan kriteria terima $\mathrm{H}_{0}$ jika nilai sig. (2-tailed) $<0,05$ yang berarti rata-rata nilai $n$-Gain kemampuan inferensi dan penguasaan konsep menggunakan discovery learning lebih tinggi daripada rata-rata nilai $n$-Gain kemampuan inferensi dan penguasaan konsep menggunakan pembelajaran kovensional dan tolak $\mathrm{H} 0$ jika sebaliknya.

Setelah itu, dialakukan uji independent sample t-test terhadap nilai pretes dan postes kedua kelas. Berdasarkan nilai t hitung yang diperoleh dari uji independent sample t-test terhadap nilai pretes dan postes, selanjutnya dilakukan perhitungan untuk menentukan ukuran pengaruh (effect size). Perhitungan uji effect size dilakukan dengan rumus sebagai berikut:

$$
\mu^{2}=\frac{\mathrm{t}^{2}}{t^{2}+d f} \quad \text { (Jahjouh, 2014) }
$$

Setelah effect size didapatkan kemudian diinterpretasikan dengan kriteria effect size menurut Dincer (2015) seperti yang ditunjukkan pada Tabel 4.

Tabel 4. Kriteri effect size

\begin{tabular}{ll}
\hline Effect Size $\left(\mu^{2}\right)$ & Kriteria \\
\hline$\mu \leq 0,15$ & Sangat kecil \\
\hline $0,15<\mu \leq 0,40$ & Kecil \\
\hline $0,40<\mu \leq 0,75$ & Sedang \\
\hline $0,75<\mu \leq 1,10$ & Besar \\
\hline$\mu>1,10$ & Sangat Besar \\
\hline
\end{tabular}




\section{HASIL DAN PEMBAHASAN}

\section{Validitas dan Reliabilitas}

Berdasarkan data hasil validitas dan reliabilitas instrumen tes yang diujicobakan kepada 20 responden, diperoleh hasil yaitu dari tiga soal uraian dinyatakan valid dan reliabel. Hasil perhitungan dengan bantuan software SPSS versi 22.0 diperoleh nilai Corrected Item Total Correlation yang menunjukkan nilai validitas butir soal uraian terdapat pada Tabel 5.

Tabel 5. Data hasil validitas soal uraian

\begin{tabular}{cccc}
\hline $\begin{array}{c}\text { Butir } \\
\text { Soal }\end{array}$ & $\mathrm{r}_{\text {hitung }}$ & $\mathrm{r}_{\text {tabel }}$ & Keterangan \\
\hline 1f & 0,538 & 0,444 & Valid \\
\hline $2 \mathrm{~g}$ & 0,877 & 0,444 & Valid \\
\hline $4 \mathrm{e}$ & 0,674 & 0,444 & Valid \\
\hline
\end{tabular}

Berdasarkan Tabel.5 dapat dilihat bahwa tiga butir soal uraian memiliki nilai rhitung > rtabel, sehingga ketiga butir soal uraian tersebut dinyatakan valid. Hasil perhitungan reliabilitas tiga soal uraian ditunjukkan dari nilai Cronbach's Alpha yaitu sebesar 0,641 yang berarti bahwa tiga soal uraian dinyatakan reliabel.

Instrumen yang baik harus memenuhi dua persyaratan penting yaitu valid dan reliabel (Arikunto, 2004). Berdasarkan hasil uji validitas dan reliabilitas, instrumen tes dengan tiga soal uraian layak digunakan untuk mengukur kemampuan inferensi dan penguasaan konsep siswa.

\section{Efektivitas Discovery Learning}

Pengamatan dan penilaian terhadap kemampuan guru mengelola pembelajaran dilakukan oleh dua orang observer dengan digunakan lembar observasi kemampuan guru dalam mengelola pembelajaran.

Berdasarkan hasil penilaian dan perhitungan yang telah dilakukan, diperoleh ratarata keterampilan guru dalam mengelola pembelajaran berkategori "tinggi" dengan ratarata persentase ketercapaian sebesar $72,56 \%$. Artinya kemampuan guru dalam mengelola pembelajaran discovery learning sudah berjalan baik yang dapat dilihat dari aspek pengamatan pendahuluan, sintak, penutup, maupun penilaian terhadap guru.

Hasil pengamatan dari kedua observer terhadap kemampuan guru dalam membelajarkan model discovery learning pada materi kesetimbangan kimia untuk meningkatkan kemampuan inferensi dan penguasaan konsep ditunjukkan pada Gambar 1.

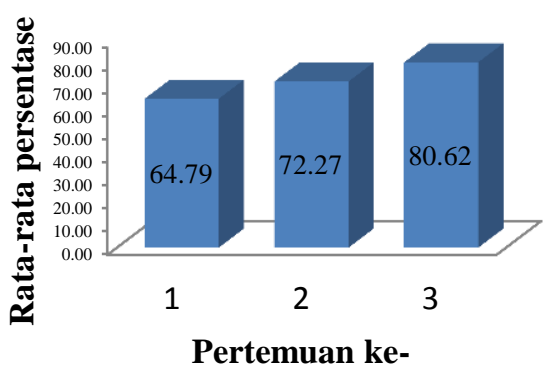

Gambar 1. Data hasil kemampuan guru dalam mengelola pembelajaran 
Berdasarkan hasil pengamatan dan penilaian terhadap kemampuan guru mengelola pembelajaran dengan penerapan model discovery learning, diperoleh bahwa pada pertemuan pertama, kedua, dan ketiga memiliki kriteria secara berturut-turut yaitu tinggi, tinggi, dan sangat tinggi. Hal ini berarti bahwa ada peningkatan kemampuan guru dalam mengelola pembelajaran menggunakan model discovery learning setiap pertemuan. Kemampuan guru dalam mengelola pembelajaran pada sintak discovery learning untuk meningkatkan kemampuan inferensi dan penguasaan konsep dapat terlihat pada tahap verifikasi dan generalisasi.

Selain pengamatan terhadap kemampuan guru mengelola pembelajaran, dilakukan juga pengamatan dan penilaian terhadap kemampuan inferensi dan aktivitas siswa selama pembelajaran. Berdasarkan hasil pengamatan dan penilaian terhadap kemampuan inferensi siswa selama pembelajaran dengan diterapkan model discovery learning diketahui bahwa ada peningkatan rata-rata kemampuan inferensi siswa pada setiap pertemuannya. Hasil pengamatan dari kedua observer terhadap kemampuan inferensi siswa ditunjukkan pada Gambar 2.

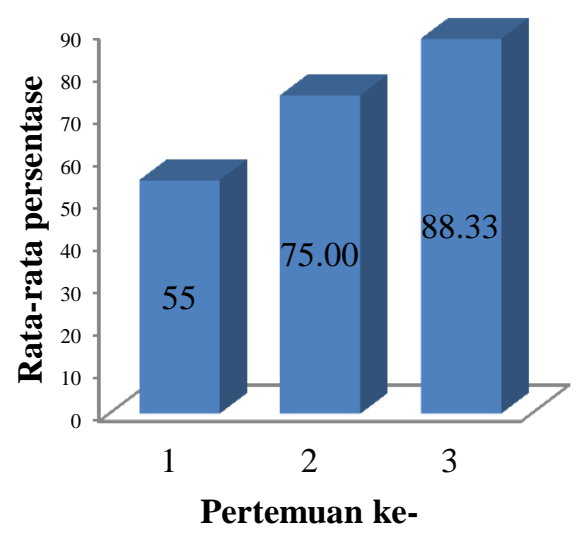

Gambar 2. Data hasil kemampuan inferensi siswa dalam pembelajaran

Berdasarkan Gambar 2 diketahui bahwa hasil pengamatan dan penilaian terhadap kemampuan inferensi siswa selama pembelajaran dengan diterapkan model discovery learning setiap pertemuan meningkat. Pertemuan pertama sebesar $55 \%$ berkriteria "sedang", pertemuan kedua 75\% berkriteria "tinggi", dan pertemuan ketiga sebesar $88,33 \%$ berkriteria "sangat tinggi" Hal ini menunjukkan bahwa terjadi peningkatan kemampuan inferensi siswa pada setiap pertemuan menggunakan pembelajaran dengan model discovery learning. Hal tersebut juga dapat terlihat dari hasil pengamatan dan penilaian aktivitas siswa. Secara keseluruhan, aktivitas siswa berkriteria "sangat tinggi". Hasil pengamatan dari kedua observer terhadap kemampuan aktivitas siswa ditunjukkan pada Gambar 3. 


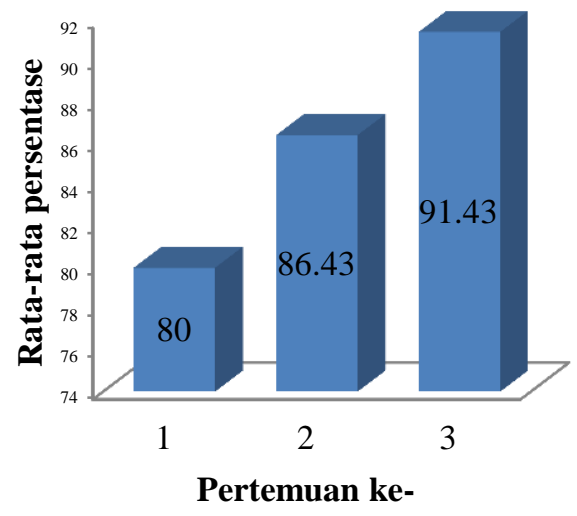

Gambar 3. Data hasil pengamatan aktivitas siswa

Berdasarkan Gambar 3 diketahui bahwa terjadi peningkatan aktivitas siswa pada setiap pertemuan dengan pembelajaran model discovery learning. Aktivitas siswa yang memiliki persentase tertinggi adalah antusias, disiplin, bersikap kritis, dan bekerjasama. Keempat aspek aktivitas tersebut sangat berpengaruh terhadap penerapan model discovery learning di kelas, sehigga siswa dapat berperan aktif dalam pembelajaran. Aktivitas tersebut sangat berpengaruh terhadap penerapan model discovery learning di kelas, sehigga siswa dapat berperan aktif dalam pembelajaran . Pembelajaran dengan model discovery learning harus dilaksanakan dengan terlibatnya siswa secara aktif untuk menemukan sendiri.

Berdasarkan hasil pengamatan terhadap kemampuan inferensi dan aktivitas siswa tersebut, diketahui bahwa dengan pembelajaran dengan model discovery learning, kemampuan inferensi dan penguasaan konsep akan terlatih dan dapat meningkat.

\section{Kemampuan inferensi dan penguasaan konsep}

Efektivitas model discovery learning diukur dari ketercapaian peningkatan kemampuan inferensi dan penguasaan konsep yang dapat dilihat berdasarkan perhitungan secara statistik. Rata-rata dari nilai pretes dan nilai postes disajikan pada Gambar 4.

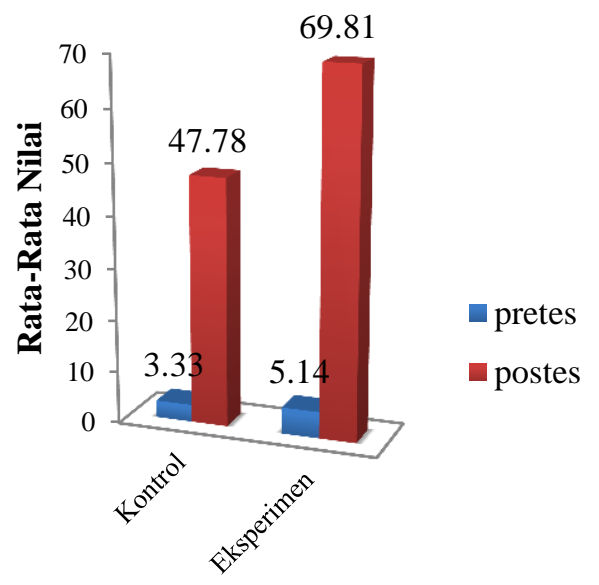

Kelas Penelitian

Gambar 4. Rata-rata nilai pretes postes 
Berdasarkan gambar tersebut dapat diketahui bahwa rata-rata nilai pretes dan postes kemampuan inferensi dan penguasaan konsep pada kelas kontrol dan kelas eksperimen terdapat peningkatan. Peningkatan nilai pretes-postes siswa dihitung dengan rumus gain ternormalisasi ( $n$-Gain) (Rismalinda, 2014). Perhitungan nilai $n$ Gain, diperoleh data rata-rata $n$-Gain untuk kelas kontrol dan kelas eksperimen yang disajikan pada Gambar 5.

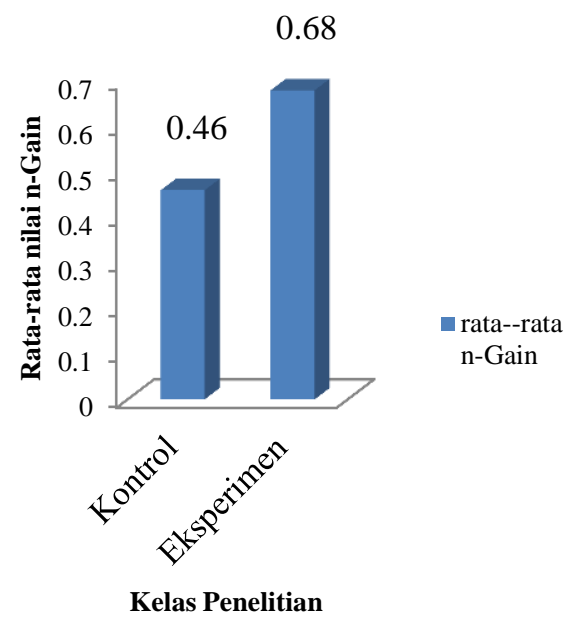

Gambar 5. Rata-rata nilai $n$-Gain

Gambar 5 menunjukkan bahwa rata-rata nilai $n$-Gain kemampuan inferensi dan penguasaan konsep pada kelas kontrol sebesar 0.46 dan pada kelas eksperimen sebesar 0.68. Berdasarkan hasil tersebut dapat diketahui bahwa rata-rata $n$-Gain kelas eksperimen lebih tinggi dibandingkan rata-rata $n$-Gain kelas kontrol.

Berdasarkan nilai pretes dan postes kemudian dihitung dan didapatkan nilai $n$ Gain. Peningkatan kemampuan inferensi dan penguasaan konsep ditunjukkan dengan adanya peningkatan nilai $n$-Gain yang digunakan untuk melihat perbandingan antara selisih nilai pretes dan postes dengan nilai maksimum dan nilai pretes sehingga dapat diketahui efektivitas model discovery learning untuk meningkatkan kemampuan inferensi dan penguasaan konsep materi kesetimbangan kimia. Hal tersebut juga didukung dengan hasil pengujian hipotesis.

\section{Uji Hipotesis}

Hasil uji normalitas dan homogenitas kemampuan inferensi dan penguasaan konsep di kelas eksperimen dan kelas kontrol dapat dilihat pada tabel berikut.

Tabel 6. Data hasil uji normalitas

\begin{tabular}{lccc}
\hline \multirow{2}{*}{ Kelas } & \multirow{2}{*}{\begin{tabular}{c} 
N \\
\cline { 3 - 4 }
\end{tabular}} & $\begin{array}{c}\text { Nilai } \\
\text { sig. }\end{array}$ & $\begin{array}{c}\text { Kriteria } \\
\text { uji }\end{array}$ \\
\hline Eksperimen & 35 & 0.058 & $\begin{array}{c}\text { Sig. }> \\
0.05\end{array}$ \\
\hline Kontrol & 36 & 0.066 & $\begin{array}{c}\text { Sig. }> \\
0.05\end{array}$ \\
\hline
\end{tabular}


Berdasarkan Tabel 6 diketahui bahwa hasil uji normalitas terhadap nilai $n$-Gain pada kelas kontrol dan kelas eksperimen, diketahui bahwa nilai sig.> 0.05, sehingga keputusan uji yaitu terima $\mathrm{H}_{0}$ dan tolak $\mathrm{H}_{1}$ yang berarti data hasil penelitian yang diperoleh berasal dari populasi yang berdistribusi normal.

Tabel 7. Data hasil uji homogenitas

\begin{tabular}{lccc}
\hline \multirow{2}{*}{ Kelas } & $\mathrm{N}$ & \multicolumn{2}{c}{$n$-Gain } \\
& & Nilai & $\begin{array}{c}\text { Kriteria } \\
\text { uji }\end{array}$ \\
\hline Eksperimen & 35 & 0.105 & Sig $>0.05$ \\
\hline Kontrol & 36 & 0.105 & \\
\hline
\end{tabular}

Berdasarkan Tabel 7 diketahui bahwa hasil uji homogenitas terhadap nilai $n$-Gain pada kelas kontrol dan kelas eksperimen, diketahui bahwa nilai sig $>0.05$, sehingga keputusan uji yaitu terima $\mathrm{H}_{0}$ dan tolak $\mathrm{H}_{1}$ yang berarti kedua sampel mempunyai nilai varians yang homogen.

\section{Uji Perbedaan Dua Rata-Rata}

Hasil uji perbedaan dua rata-rata dengan uji Independent Sample T-Test pada kelas eksperimen dan kelas kontrol disajikan pada Tabel 8.

Tabel 8. Data hasil uji Independent Sample T-Test

\begin{tabular}{|c|c|c|c|c|}
\hline Kelas & $\mathrm{N}$ & $\begin{array}{c}n- \\
\text { Gain }\end{array}$ & $\begin{array}{l}\text { Sig(2- } \\
\text { tailed })\end{array}$ & $\begin{array}{c}\text { Kriteri } \\
\text { a Uji }\end{array}$ \\
\hline Eksperimen & 35 & 0.68 & \multirow{2}{*}{0.00} & Sig(2- \\
\hline Kontrol & 36 & 0.46 & & $\begin{array}{l}\text { talled) } \\
<0,05\end{array}$ \\
\hline
\end{tabular}

Tabel di atas menunjukkan bahwa nilai sig (2-tailed) $<0,05$, sehingga keputusan uji yaitu terima $\mathrm{H}_{0}$ dan tolak $\mathrm{H}_{1}$ yang berarti ada perbedaan yang signifikan pada ratarata nilai $n$-Gain pada kelas eksperimen dan kelas kontrol. Rata-rata nilai $n$-Gain kemampuan inferensi dan penguasaan konsep di kelas eksperimen yang diterapkan model discovery learning lebih tinggi daripada rata-rata nilai $n$-Gain kemampuan inferensi dan penguasaan konsep di kelas kontrol yang diterapkan model konvensional pada materi kesetimbangan kimia.

\section{Ukuran Pengaruh (Effect Size)}

Setelah melakukan uji-t terhadap nilai n-Gain, selanjutnya untuk mendapatkan seberapa besar pengaruh efektivitas discovery learning dengan dilakukan perhitungan effect size yang sebelumnya harus diketahui terlebih dahulu nilai $t$ dari hasil uji-t terhadap nilai pretes dan postes pada kedua kelas yang dapat ditunjukkan pada Tabel 9.

Tabel 9. Data hasil perhitungan effect size

\begin{tabular}{ccccc}
\hline \multirow{2}{*}{$\begin{array}{c}\text { Aspek yang } \\
\text { diuji }\end{array}$} & \multicolumn{2}{c}{ Kelas } & \multicolumn{2}{c}{ Kelas Kontrol } \\
\cline { 2 - 5 } & $\begin{array}{c}\text { Effect } \\
\text { Size }\end{array}$ & Kriteria & $\begin{array}{c}\text { Effect } \\
\text { Size }\end{array}$ & Kriteria \\
\hline $\begin{array}{c}\text { Kemampuan } \\
\text { Inferensi }\end{array}$ & 0,75 & $\begin{array}{c}\text { Efek } \\
\text { Sedang }\end{array}$ & 0,87 & $\begin{array}{c}\text { Efek } \\
\text { Besar }\end{array}$ \\
\hline
\end{tabular}


Berdasarkan Tabel 9 menginformasikan bahwa pada kelas eksperimen pembelajaran dengan model discovery learning memiliki pengaruh "besar" dalam meningkatkan kemampuan inferensi dan penguasaan konsep materi kesetimbangan kimia. Pada kelas kontrol yang menggunakan pembelajaran konvensional memiliki pengaruh "sedang" dalam meningkatkan kemampuan inferensi dan penguasaan konsep materi kesetimbangan kimia. Sehingga dapat diketahui bahwa pembelajaran menggunakan model discovery learning memiliki pengaruh yang lebih besar untuk meningkatkan kemampuan inferensi dan penguasaan konsep materi kesetimbangan kimia.

Berdasarkan kemampuan guru dalam mengelola pembelajaran, uji perbedaan dua rata-rata, dan uji pengaruh serta didukung pula dengan hasil pengamatan aktivitas dan kemampuan inferensi siswa menunjukkan bahwa pembelajaran menggunakan model discovery learning lebih baik dalam meningkatkan kemampuan inferensi dan penguasaan konsep dibandingkan menggunakan pembelajaran konvensional.

Hal tersebut sesuai dengan teori Burner, belajar dengan penemuan sesuai dengan pencarian pengetahuan secara aktif oleh manusia dan dengan sendirinya memberikan hasil yang paling baik (Dahar, 2011). Hasil ini juga didukung dengan penelitian Kusuma (2018) yang menyatakan bahwa model discovery learning dapat meningkatkan keterampilan proses sains serta penelitian Mahmudah (2016) juga menunjukkan bahwa terdapat hubungan antara keterampilan proses sains dan penguasaan konsep.

\section{KESIMPULAN}

Berdasarkan hasil penelitian yang telah diperoleh, disimpulkan bahwa pembelajaran menggunakan model discovery learning efektif dalam meningkatkan kemampuan inferensi siswa dan penguasaan konsep pada materi kesetimbangan kimia serta memberikan pengaruh yang besar terhadap kemampuan inferensi dan penguasaan konsep.

\section{DAFTAR RUJUKAN}

Arikunto, Suharsimi. 2006. Prosedur Penelitian. Jakarta: Rineka Cipta.

Dahar, R. W. 2011. Teori Belajar dan Pembelajaran. Jakarta: Erlangga.

Dimyati dan Mudjiono. 2002. Belajar dan Pembelajaran. Jakarta: Rineka Cipta

Dincer, S. 2015. Effect Of Computer Assisted Learning On Students Achievementin Turkey: a Meta-Analysis. Journal Of Turkish Science Education, Vol 12. No 1.

Djamarah, Syaiful Bahri dan Zain, Aswan. 2010. Strategi Belajar Mengajar. Jakarta: PT. Asdi Mahasatya.

Fadiawati, N. 2011. Perkembangan Konsepsi Pembelajaran Tentang Struktur Atom dari SMA Hingga Perguruan Tinggi. (Disertasi). Bandung: SPs-UPI Bandung.

Fidiana, E. Rudibyani., Tania, L. 2017. Penerapan Model Discovery Learning untuk Meningkatkan Keterampilan Berpikir Luwes Siswa pada Materi Larutan Penyangga (Skripsi). Bandar Lampung: FKIP Universitas Lampung.

Fraenkel, J. R., N. E. Wallen., dan H. H. Hyun. 2012. How To Design and Evaluate Research In Education Eighth Edition. New York: The Mc Graw Hill Companies.

Hake, R.R. 2002. Interactive Engagement Versus Traditional Methods: A Six Thousand Student Survey of Mechanics Test Data For Introductory Physics Courses American. Journal of Physics, Vol. 66. No. 1. 
Hosnan, M. 2014. Pendekatan Saintifik dan Kontekstual dalam Pembelajaran Abad 21. Bogor: Penerbit Ghalia Indonesia.

Jahjouh, Y.M.A. 2014. The effectiveness of Blended E-Learning Forum In Planning For Science Instruction Journal Of Turkish Science Education, Vol 11. No 4.

Joolingen, W.V. 1998. Cognitive Tools for Discovery Learning. Inter. J. Artific. Intel. Educ., Vol 1. No. 10

Kosasih, E. 2014. Strategi Belajar dan Pembelajaran. Bandung: Yrama Widya.

Kurniasih, I dan Sani, B. 2014. Sukses Mengimplementasikan Kurikulum 2013. Jakarta: Kata Pena.

Kusuma, N. W. 2018. Deskripsi Sikap Ilmiah dan Peningkatan Keterampilan Proses Sains Pada Materi Larutan Elektrolit dan Non Elektrolit Menggunakan Model Discovery Learning. (Skripsi). Bandar Lampung: Universitas Lampung. Tidak dipublikasikan.

Mahmudah, Umi. 2016. Hubungan Keterampilan Proses Sains Dengan Penguasaan Konsep Peserta Didik Kelas XI Man 1 Pati pada Materi Asam Basa dan Larutan Penyangga. (Skripsi). Semarang: Universitas Islam Negeri Walisongo.

Rismalinda, A. 2014. Pembelajaran Menggunakan Pendekatan Ilmiah dalam Meningkatkan Keterampilan Berpikir Lancar pada Materi Kesetimbangan Kimia. (Skripsi). Bandar Lampung: Universitas Lampung. Tidak dipublikasikan.

Rosaria, A. 2018. Efektivitas Discovery Learning untuk Meningkatkan Keterampilan Berpikir Elaborasi dan Penguasaan Konsep Asam Basa Arrhenius. (Skripsi). Bandar Lampung: Universitas Lampung

Rustaman. 2005. Pengembangan Konsep. Bandung: Remaja Rosdakarya.

Sukawati, D.T. 2016. Efektivitas Model Discovery Learning pada Materi Larutan Penyangga dalam Meningkatkan Keterampilan Mengelompokkan dan Mengomunikasikan. (Skripsi). Bandar Lampung : Universitas Lampung. Tidak dipublikasikan.

Sunyono. 2013. Buku Model Pembelajaran Berbasis Multiple Representasi (Model SiMaYang). Bandar Lampung: Aura Printing dan Publishing.

Suprayanti, dkk. 2016. Penerapan Model Discovery Learning Berbantuan Alat Peraga Sederhana untuk Meningkatkan Aktivitas dan Hasil Belajar Siswa Kelas VII SMPN 5 Jonggat Tahun Pelajaran 2015/2016. Jurnal Pendidikan Fisika dan Teknologi,. Vol 2. No. 1.

Trianto. 2010. Model Pembelajaran Terpadu. Jakarta: Bumi Aksara. 